\title{
Catholic Church is the Divinity Symbol with the Case Study of Santa Theresia Church in Jakarta, Indonesia
}

\author{
Rudy Trisno ${ }^{\# 1}$, Fermanto Lianto*2 \\ \# Architecture Department, Tarumanagara University \\ S. Parman No. 1, Jakarta 11440, Indonesia \\ ${ }^{1}$ rudyt@ft.untar.ac.id \\ 2 fermantol@ft.untar.ac.id
}

\begin{abstract}
This research aims to trace the liturgical relation with the spatial configuration with the Catholic Church architecture form. The methodology used in this research is first, recording Church building of Santa Theresia then re-draw it in three dimensional (3D) to analyse the entire Church architectural formation and its ornament. Second, are the combination of the sacred approaches from Eliade, Hoffman, Jones, and Barrie, while the liturgy of the Catholic Church is using the approach from Martasudjita and the architectural alignment is using the approach from Salura where the study case started with the anatomy from the environment scope, site scope, building, and figure scope. All of these are to explore the sacred concept of the function of liturgy that linked to its form. The results concluded that the Catholic Church form is a symbol of divinity and ideogram. Thus if the scope of the environment, the sites, the building and the figure corresponds to the aspect of creating sacred values, the whole architecture of Santa Theresia's Church can be stated to radiate a sacred expression.
\end{abstract}

Keyword - Catholic Church, Divinity Symbol, Architectural Formation, Ideogram

\section{INTRODUCTION}

The phenomenon of the form of the Catholic Church after Vatican II is diverse because of technological advances and the absence of clear rules for the architecture shape of the Catholic Church

The phenomenon of Catholic Church architecture form is the cause of the faded architecture form of Catholic Church. The problem of fade of the Catholic Church's architecture form actually took place before the Second Vatican Council, but after the Second Vatican Council the fade of the sacred values of both the inner and the outer space of the Catholic Church also increasing.

The fading issue of the sacred value of the form of Catholic Church was not caused by the Second Vatican Council but it is because of the misinterpretation of the policy from the Second Vatican Council [1], therefore, the issue of fading form of architecture in the Catholic Church is appealing to be a topic for this study.

The issue of fading form of architecture in the Catholic Church gained special attention from Pope Benedict XVI, therefore he sent Cardinal Antonio Canizares Llovera as chairman of the Congregation for Divine Worship and The Discipline of the Sacraments committee to overcome this problem by creating Instruction IV as a response to this problem [2]. The main issue in this research is the relationship between the liturgical function with the architectural form which includes the spatial configuration.

The use and benefits derived from this research are: First, deep understanding of the sacred Catholic Church form of architecture; Second, to add the theoretical glossary about the dynamics of the relationships between the functions and the form as well as the spatial configuration; Third, giving specific input to all stakeholders about the form of a Catholic Church that is in line with Catholic values; Fourth, to put a position of the development of the sacred value of the Catholic Church in the context of an increasingly globalized world.

\section{Material And Method}

In principle, the analysis based on the relationship aspect of the architectural forms and function; although it is realized that in a reality, the two aspects above cannot be separated [3]. But for this study, the emphasis will be only on the analysis of the relationship between the functional aspects and the form.

The first step is to describe all of the liturgical activities in the Catholic Church. The breakdown of liturgical activities is conducted on weekly periodic activities basis [4]. This recording is being conducted using Martasudjita's approach [5] and the symbolic liturgy [6] is composed of the Profane-Sacral, which includes Narthex, Nave and Sanctuary as shown in Fig. 1. 


\begin{tabular}{|c|c|c|c|c|}
\hline \multicolumn{5}{|c|}{ DESCRIPTION OF PROCESS LITURGICAL } \\
\hline Preparation & $\begin{array}{l}\text { Opening } \\
\text { Ritual }\end{array}$ & $\begin{array}{l}\text { The liturgy of the } \\
\text { word }\end{array}$ & $\begin{array}{c}\text { The liturgy of } \\
\text { Eucharist }\end{array}$ & $\begin{array}{l}\text { Closing } \\
\text { Ritual }\end{array}$ \\
\hline $\begin{array}{l}\text { People take holy } \\
\text { water and } \\
\text { making cross } \\
\text { symbol as sign of } \\
\text { purification }\end{array}$ & $\begin{array}{l}\text { Song, } \\
\text { Penitential rite, } \\
\text { Gloria, and } \\
\text { Opening } \\
\text { prayers }\end{array}$ & $\begin{array}{l}\text { The dialogue encounter } \\
\text { within he God words } \\
\text { (Reading designated } \\
\text { passage) and people } \\
\text { response. }\end{array}$ & $\begin{array}{l}\text { It is the peak of the } \\
\text { liturgy. The essence } \\
\text { of the Eucharistic } \\
\text { liturgy is the } \\
\text { Eucharistic Prayer } \\
\text { and Communion. }\end{array}$ & $\begin{array}{l}\text { Announcement, } \\
\text { closing prayer, } \\
\text { and ending it } \\
\text { by the priest } \\
\text { asking the } \\
\text { people to } \\
\text { spread the }\end{array}$ \\
\hline $\begin{array}{l}\text { NARTHEX } \\
\text { Terrace- seating } \\
\text { area border. [the } \\
\text { baptism vessel] }\end{array}$ & & $\begin{array}{l}\text { AVE } \\
\text { people seat }\end{array}$ & $\begin{array}{l}\text { SANCTUARY } \\
\text { The priest's } \\
\text { place where } \\
\text { there is an altar }\end{array}$ & $\begin{array}{l}\text { Word of God } \\
\text { and put it into } \\
\text { practice. }\end{array}$ \\
\hline \multicolumn{5}{|c|}{ ACTIVITY ZONE } \\
\hline
\end{tabular}

Fig.1. Liturgy Symbol.

The concept of sacred value in the liturgy requires the imagination of the spatial dimensions and sacred forms derived from the Eliade [7], displays the axis mundi as the centre of the world and it is sublimated to the sacral building, as a sacral orientation. Eliade take an example of the mountain as the embodiment of the axis mundi as the highest orientation has the most sacred value. Jones [8], develops orientation, symmetrical axis, spatial order and form based on hierarchical concepts, monumental scale, and light arrangement to create sacred expressions. Another sacred expert is Barrie [9], he reveals spatial sequences based on the hierarchical concepts and balancing principles underlying the creation of the sacral geometry. Hoffman [10], is an architect who has done sacred studies that exposes the identification of architectural elements inside and outside the building, the archetypal indication elements, and atmospheric ambiguities. We search for the conformity from all of the approaches including the liturgy approach according to Martasudjita and also the sacred approach according to Eliade, Jones, Barrie, and Hoffman. The conformity is the spatial configuration aspect which includes location, orientation, hierarchy, spatial arrangement, zoning sequence, and axis as well as the conformity of the aspects of the form of the building which includes the composition, appearance, scale, color material, ornamentation, and texture.

The Salura Approach [11] covers the scope of anatomy i.e. the scope of the figure, the scope of the building, the scope of the site and the scope of the environment as shown in Fig. 2. The sacred concept of the liturgy is analysed in the Church of Santa Theresia in Jakarta, Indonesia.

The second step is to conduct an analysis based on the framework for the case study interpretation at the Santa Theresia's Church in Jakarta, Indonesia. The Church was first open with an anatomical scope approach from Salura [12] and it includes the Environmental Scope, Scope of Site, Scope of the Building and Scope of the Figure as shown in Fig. 2. 


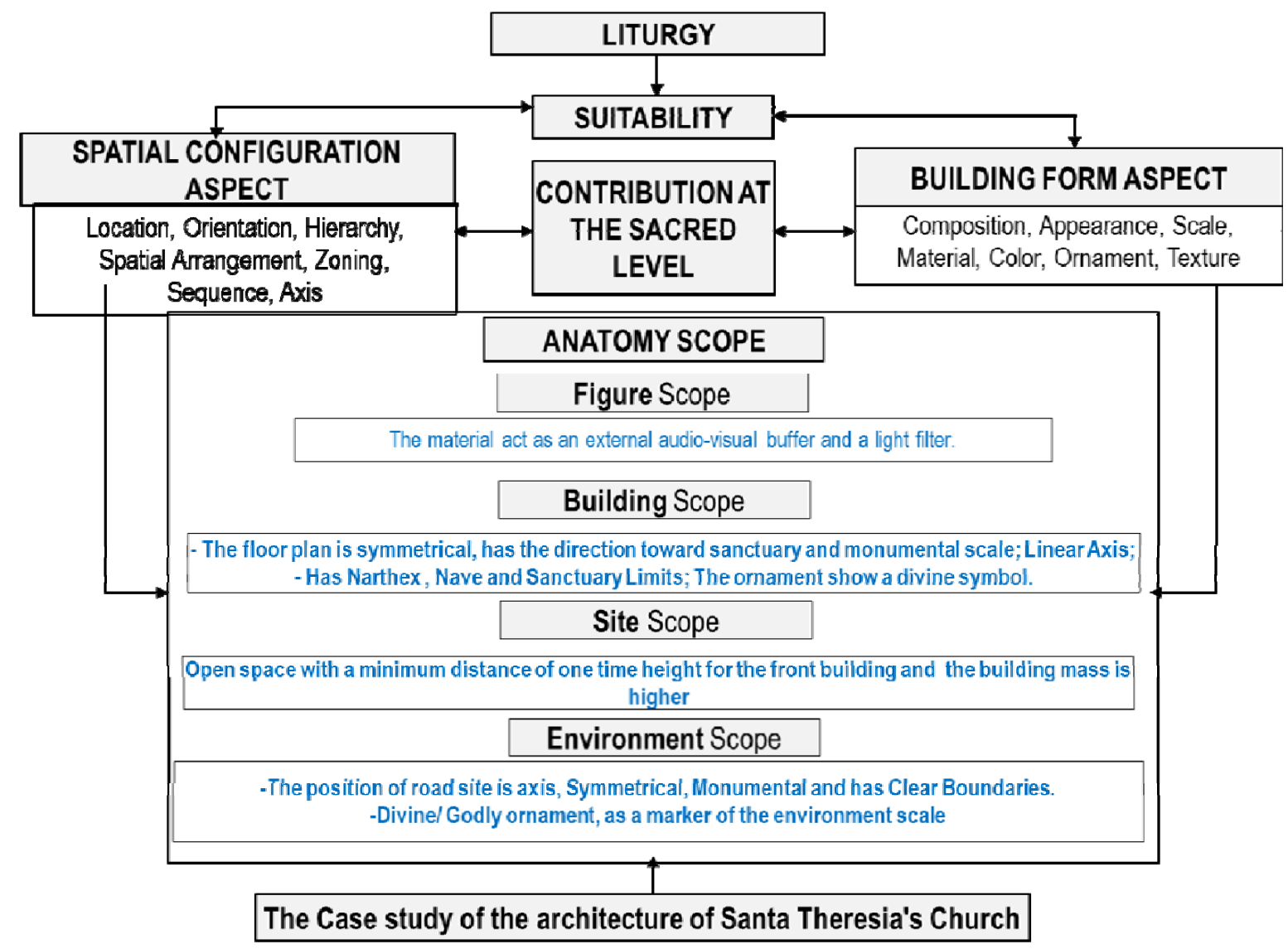

Fig.2. Reference framework for the interpretation of study cases.

The first step encompasses the conformity between functions (liturgy), with the concepts that include aspects of the shape and aspects of spatial configuration that contributes to the level of sanctity. The second step is the anatomical scope of the Santa Theresia Church. Hence, from this first and second step we could obtain the meaning of the sacred value from Santa Theresia's Church as shown in Fig.2.

\section{RESULTS AND DISCUSSION}

The Relationship of the Liturgy between the aspect of Form and aspect Spatial Configuration, from the Architecture of the Catholic Church.

The liturgical relation between the aspect of form and aspect spatial configuration, from the Catholic Church architecture is to obtain the true meaning of sacred value. Whether or not this relationship supports the sacred value. The description of the sacred analysis is as follows:

Firstly, all of the environmental spheres that have the potential to create sacred value with the indicator of the position of the tread on the road axis, symmetrical, monumental and clear boundaries are fulfilled. The next indicator is the presence of the ornamentation of the divine symbol as a marker on the environmental scope.

Secondly, all of the scope of the tread that potentially creates sacred value is fulfilled by open space indicator with a minimum distance of one time the height of the building in front of it and high building mass.

Thirdly, all of the scope of the building that has the potential to create a sacred value are fulfilled by symmetrical plan-type indicator and has a facing direction compared to the centre and monumental scale. The next indicator in the building scope is the clear boundaries that marks the Narthex-Nave-Sanctuary zone, as well as the linear axis that links the Narthex-Nave-Sanctuary. The last indicator in the building scope is the ornamentation that tends to link with symbolic divinity.

Fourthly, all of the scope of a figure that potentially creates a sacred value is fulfilled by a wall indicator that is not only the audial and visual buffer, but also a light filter. The brief description of this sacred analysis can be seen in TABLE I. 
TABLE I. Liturgy relationship with form and spatial configuration of the architecture of Catholic Church.

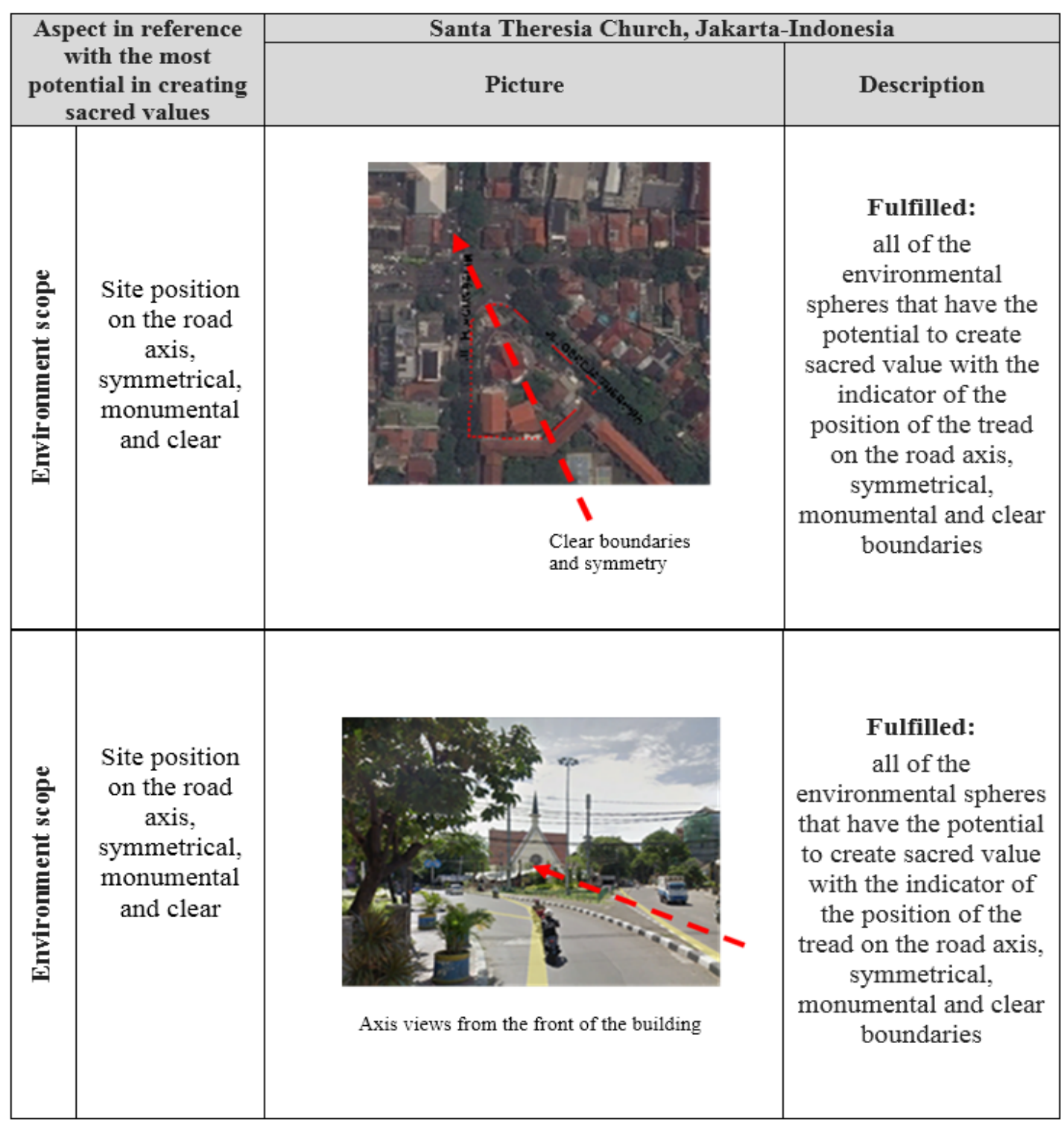




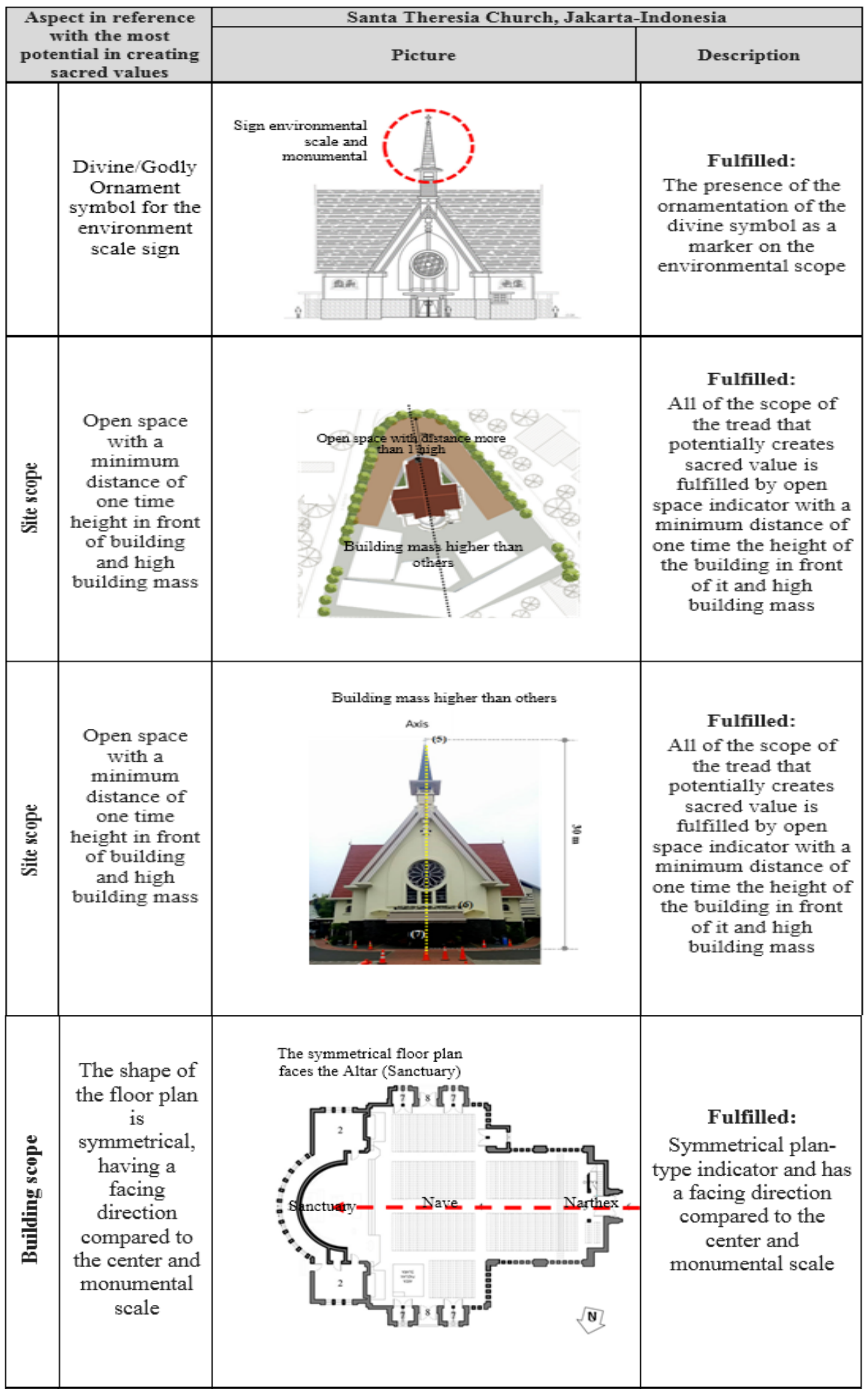




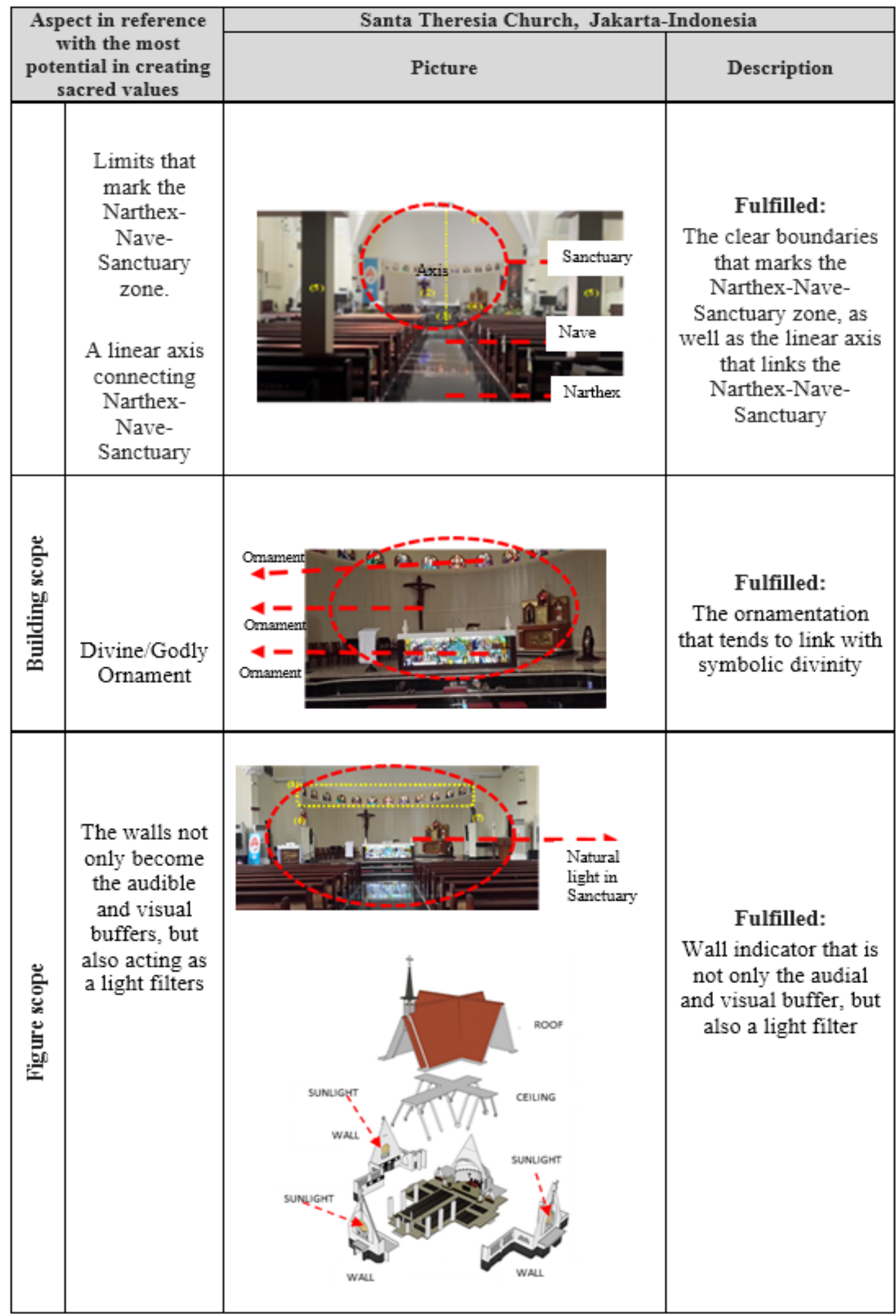

Based on the description of TABLE I, it can be concluded that:

First, the most potential reference aspect in creating a sacred value are the scope of the environment the scope of the site, the scope of the building, and the scope of the figure in the analysis of TABLE I are all fulfilled.

Second, the form of the inner space and outer space has a divine ornament that can be regarded as a symbol of divinity/Godly symbol, so that all these findings are leading to sacred values.

Third, the spatial configuration of the liturgy is inclined towards the higher sanctuary, this spatial configuration is regarded as ideogram, ideogram is the idea of motion and sign, the ideal three-dimensional form of rules is based on the liturgy as shown in Fig. 3. 


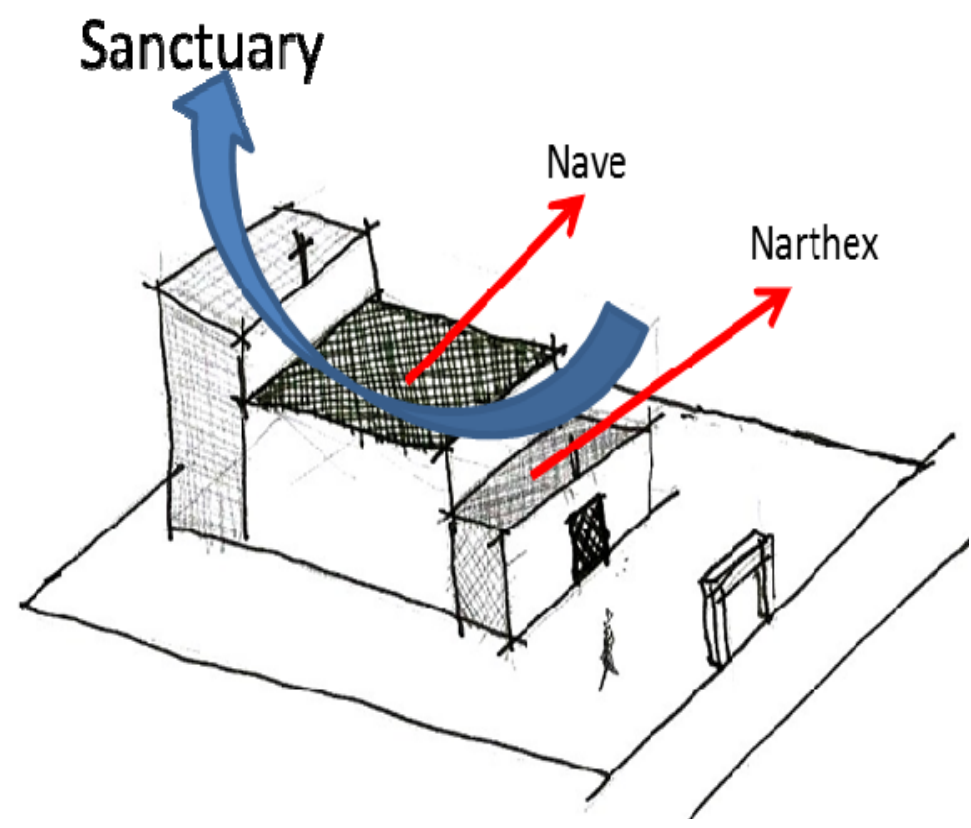

Fig.3. Ideogram.

\section{ConCLuSION}

Based on the results of the analysis, it can be concluded that:

The relationship of the liturgy to the form and spatial configuration of Santa Theresia's Church in Jakarta Indonesia has the interconnecting relationship. This relationship will give the sacred value from outside the building as well inside the building.

The study formulated a new reading and the operational steps in uncovering the relationship between the liturgy with the aspect form and aspect spatial configuration of the Santa Theresia's Church in Jakarta-Indonesia by further elaborating and cross referencing Eliade, Hoffman, Jones, Barrie, Martasudjita and Salura approaches to achieve a sacred concept. From the formulation in this study, it can be concluded that the inner and outer space form of the Catholic Church is a divine symbol/Godly Symbol while the spatial configuration is the ideogram (liturgy).

The sacred concept of the Catholic Church form in which will act as a symbol of deity and ideogram is particularly important to be deeply understood, especially in the design of the Catholic Church and also in the general architecture as this issue is a major issue in the architecture field.

A deep understanding of the relationship between the liturgy and the aspect of form and aspect spatial configuration from Catholic Church architecture will be very useful in positioning the sacred value for the concept of the Catholic Church as well as on the development of architectural Church formation that tends to get more diverse in global developments.

\section{ACKNOWLEDGMENT}

I would like to express my sincere gratitude to the teaching staff and friends from the architecture department of Parahyangan Catholic University and Tarumanagara University, who has supported the research. This study can be useful for those who would like to study the sacred value of Catholic Church architecture that is associated with the liturgy with the spatial configuration aspects and the form of the building.

\section{REFERENCES}

[1] Llovera. (2014, July), http://vaticaninsider.lastampa.it, Retrieved July 2014.

[2] D. Y. Srisadono, Konsep Sacred Space dan Penerapannya dalam Gereja Katolik. Journal Melintas, 28(2), 2012, pp.182-206.

[3] P. Salura \& B. Fauzy, The Ever-rotating Aspects of Function-Form-Meaning in Architecture. International Journal of Basic and Applied Scientific Research, 2(7), 2012, 7086-7090.

[4] K. W. Gereja, Pedoman Umum Missale Romawi. Jakarta: Nusa Indah, 2002, p.106.

[5] E. Martasudjita, Liturgi Pengantar untuk Studi dan Praksis Liturgi. Yogyakarta: Kanisius, 2011, p. 44.

[6] F. Dillistone, The Power of Symbols. Yogyakarta: Kanisius, 2002, p.13.

[7] M. Eliade, The Sacred and The Profane. (Nurwanto, Trans.) Yogyakarta: Fajar Pustaka Baru, 2002, pp. 7, 30-33, 39, 48-49, $174,183$.

[8] L. Jones, The Hermeneutics of Sacred Architecture, Volume 2. Cambridge, Massachussetts: Harvard University Press, 2000, pp. 266293, 296-309.

[9] T. Barrie, The Sacred In-between The Mediating Roles of Architecture. New York: Routledge, 2010, pp. 75, 176-177.

[10] D. R. Hoffman, Seeking the Sacred in Contemporary Religious Architecture. Ohio: The Kent State University Press, 2010, pp. 13-41.

[11] P. Salura, Sebuah Kritik: Arsitektur Yang Membodohkan. Jakarta: Gakushudo Publishing, 2015, pp. 120-124. 


\section{AUTHOR PROFILE}

Rudy trisno is a lecturer (associate professor), practitioner in architect and interior design, currently teaching architecture in Tarumanagara post graduate program. Architecture scholar education is taken at University of Tarumangara, Architecture post-graduate education at Trisakti University and Architecture doctoral education at Parahyangan Catholic University. Interested in building design especially sacred buildings.

Fermanto Lianto is a lecturer and practitioner in architect, currently teaching architecture in Tarumanagara post graduate program. Architecture scholar education is taken at University of Tarumangara, Engineering postgraduate education at Tarumanagara University and Architecture doctoral education at Parahyangan Catholic University, Indonesia. 